\title{
Clinical Study of Morbidity and Mortality Pattern of Preterm Very Low Birth Weight Babies in Neonatal Period
}

\author{
Dr. Md. Alamgir Hossain ${ }^{1 *}$, Dr. Md. Kamrul Hasan Rafy², Dr. Afsana Rahman ${ }^{3}$, Dr. Md. Monir Hasan ${ }^{4}$, Dr. Md. Golam
} Azam $^{5}$

\footnotetext{
${ }^{1}$ Assistant Professor, Department of Paediatrics, Patuakhali Medical College, Patuakhali, Bangladesh

${ }^{2}$ Honorary Medical Officer, Department of Anaesthesia and Critical Medicine, Faridpur Medical College, Faridpur, Bangladesh

${ }^{3}$ Honorary Medical Officer, Department of Gynae and Obstetrics, Faridpur Medical College, Faridpur, Bangladesh

${ }^{4}$ Assistant Professor, Dept. of Paediatrics, OSD, DGHS, MOHFW, Jashore Medical College, Jashore, Bangladesh

${ }^{5}$ Assistant Professor, Department of Pediatrics, Brahmanbaria, Medical College \& Hospital, Brahmanbaria, Bangladesh
}

DOI: $10.36347 /$ sjams.2022.v10i01.014

| Received: 01.12.2021 | Accepted: 06.01.2022 | Published: 19.01.2022

*Corresponding author: Dr. Md. Alamgir Hossain

Assistant Professor, Department of Paediatrics, Patuakhali Medical College, Patuakhali, Bangladesh

Abstract

Original Research Article

Background: There are multiple factors responsible for preterm delivery. It is difficult to completely separate factors associated with prematurity from those are associated with 'IUGR [4]. Objective: To determine morbidity and mortality pattern of preterm very low birth weight babies in neonatal period. Methods: A total number of 200 preterm very low birth weight babies consecutively admitted in this hospital were enrolled into this study. The information about the babies gathered from the history and physical examination and recorded within 24 hours of admission. Each infant was reassessed daily to record the progress and to document any new complication. In his study $50 \%$ was male and $50 \%$ was female babies. Among them $8.5 \%$ was extremely Low birth weight, $1.5 \%$ was incredibly low birth weight babies. About $64.5 \%$ of preterm VLBW babies were associated with multiple pregnancy- among them $57.1 \%$ twin pregnancy and $7.5 \%$ triplet pregnancy. Each baby had one or more problems -infection 33\% (septicemia congenital pneumonia and umblical sepsis), perinatal asphyxia 30\%, poor feeding $10 \%$, neonatal jaundice 28.5 , neonatal seizure $14 \%$, apnea $16.5 \%$, RDS $5 \%$, Hypoglycemia $7 \%$, hypocalcaemia $2.5 \%$, were the major problems. Result: Among the studied neonates mortality rate was $32.5 \%$. Perinatal asphyxia 30\%, septicemia. $20.50 \%$ were the major cause of death in preterm infants. Immediate outcome of preterm VLBW infants was closely related to maternal illness during pregnancy. We found mortality rate was related to gestational age, highest (100\%) among the babies of gestational age less than 28 weeks and lowest in babies of gestational age 35 weeks or more. Lower gestational age was associated with higher mortality rate. Higher mortality rates were observed among babies delivered vaginally $(24.7 \%)$ compared to caesarian section $(16.7 \%)$. In addition to prematurity-birth weight was the important factor influencing the mortality observed in the present study. Conclusion: This study was an enthusiastic approach towards finding out morbidity and mortality pattern the outcome in preterm very low birth weight babies in neonatal period.

Keywords: Preterm, very low birth weight, neonates, gestational age.

Copyright $\odot \mathbf{2 0 2 2}$ The Author(s): This is an open-access article distributed under the terms of the Creative Commons Attribution 4.0 International License (CC BY-NC 4.0) which permits unrestricted use, distribution, and reproduction in any medium for non-commercial use provided the original author and source are credited.

\section{INTRODUCTION}

Chronic maternal disease such as UTI, hypertension, diabetes mellitus is associated with premature birth [1]. Prematurity is related to extra difficulty to adaptation with extra uterine environment compared to term baby due to their immaturity of organ system. Premature infants may adapt poorly to air breathing. Apnea of premature babies occurs in $25 \%$ of preterm low birth weight babies [2]. It is higher in of preterm very low birth weight babies Apneic spell is one of the major causes of death in preterm babies [3]. Incidence of respiratory distress syndrome in preterm very low birth weight babies is $13.43 \%$ [4]. (The incidence is $1-3 \%$ of all birth). It is $5 \%$ of infants born at 36 weeks and $25 \%$ born at 28 weeks. The incidence increases with increased prematurity [5]. It is an important cause of death of preterm very low birth weight babies. Immature cerebral vasculature predispose to subependymal or intra ventricular hemorrhage (IVH). The incidence is $20-30 \%$ in infants born at less than 31 weeks and as low as 26 weeks of gestational age [6].

In preterm infants impaired absorption of substrate by the intestine compromise the nutritional

Citation: Dr. Md. Alamgir Hossain, Dr. Md. Kamrul Hasan Rafy, Dr. Afsana Rahman, Dr. Md. Monir Hasan, Dr. Md. Golam Azam. Clinical Study of Morbidity and Mortality Pattern of Preterm Very Low Birth Weight Babies in Neonatal Period. Sch J App Med Sci, 2022 Jan 10(1): 87-91. 
Md. Alamgir Hossain et al; Sch J App Med Sci, Jan, 2022; 10(1): 87-91

management. Necrotizing enterocolitis is the most common acquired emergency in neonate [7]. Prematurity contributes $20 \%$ of the affected infants with necrotizing enterocolitis [8]. Preterm very low birth weight infants are more vulnerable to infection than term babies [9-11]. The mode of delivery was found to influence the outcome of the preterm infants. It is found that outcome is better of preterm babies delivered by caesarian section than vaginal delivery [9-11].

\section{OBJECTIVES}

General objectives

To determine morbidity and mortality pattern of preterm very low birth weight babies in neonatal period.

\section{Specific objectives}

1. To determine the outcome of preterm very low birth weight babies in neonatal period.

2. To identify important perinatal risk factors associated with preterm very low birth weight baby's contribution to morbidity and mortality pattern of preterm very low birth weight babies in neonatal period.

\section{Methodology}

\begin{tabular}{|l|l|}
\hline Type of study & Prospective study \\
\hline Place of study & $\begin{array}{l}\text { Special care Neonatal Unit of Pediatrics department of Sher-e- Bangla medical college } \\
\text { hospital, Barisal }\end{array}$ \\
\hline Study period & Two years (from August 2019 to August 2021) \\
\hline Study population & 200 case (Male baby-100, Female baby- 100). \\
\hline $\begin{array}{l}\text { Sampling } \\
\text { technique }\end{array}$ & Purposive \\
\hline
\end{tabular}

\section{Selection Criteria}

\section{Inclusion criteria}

a. Preterm -Gestational age from 28 weeks to $<37$ weeks.

b. Very low birth weight -Birth weight from $700 \mathrm{gm}$ to $<1500 \mathrm{gm}$.

c. Post-natal age 0-48 hours.

\section{Exclusion criteria}

a. Gestational age from $<28$ weeks and $>37$ weeks.

b. Birth weight from $<700 \mathrm{gm} \&>1500 \mathrm{gm}$.

c. Post-natal age $>48$ hours.

d. Babies with any obvious congenital anomaly and moribund patient.

\section{Study procedure}

After fulfilling the inclusion criteria verbal consent was taken from attendant or mother of the baby. Two hundred (200) preterm very low birth weight babies were included in this study. They were admitted to neonatal unit of pediatrics ward of Sher-e-Bangla Medical College Hospital, Barisal during the period from August 2019 to August 2021.

For each infant history was taken and physical examination was done as per set questionnaire. Obstetrical history was taken from the attended and from the birth record. Gestational age of the infant was determined by the history of date of mother's last menstrual period and was confirmed by New Ballard Scoring (NBS) system.

Weight was taken by the digital weight machine. Daily weight was taken by the same machine and at the same time before feeding.

There were junior doctors on duty round the clock in neonatal unit and supervised by the pediatrics consultant. I visited every VLBW baby twice daily.

Any pathological state if present was recorded and management reviewed according to the clinical stat. Handling of the baby was kept at minimum level for prevention of infections.

\section{RESULT}

Table-I: Distribution of babies according to age at admission

\begin{tabular}{|l|l|l|}
\hline Age at admission & Number & Percent (\%) \\
\hline Up to 12 hours & 75 & $37.5 \%$ \\
\hline $13-24$ ours & 90 & $45 \%$ \\
\hline$>24$ hours & 35 & $17.5 \%$ \\
\hline
\end{tabular}

Distribution of babies according to age at follows

Out of 200 babies 75 babies got admitted within 12 hours of birth, 90 babies within 13-24 hours and 35 babies at $>24$ but $<48$ hours of birth. 
Md. Alamgir Hossain et al; Sch J App Med Sci, Jan, 2022; 10(1): 87-91

Table-II: Distribution of babies in relation to gestational age

\begin{tabular}{|l|l|l|}
\hline Gestational age (week) & Number babies (n) & Percent (\%) \\
\hline 28 & 03 & $1.5 \%$ \\
\hline 29 & 07 & $3.5 \%$ \\
\hline 30 & 12 & $6 \%$ \\
\hline 31 & 15 & $7.5 \%$ \\
\hline 32 & 40 & $20 \%$ \\
\hline 33 & 35 & $17.5 \%$ \\
\hline 34 & 34 & $17 \%$ \\
\hline 35 & 29 & $14.5 \%$ \\
\hline 36 & 20 & $10 \%$ \\
\hline$<37$ & 05 & $2.5 \%$ \\
\hline Total & 200 & $100 \%$ \\
\hline
\end{tabular}

Distribution of Preterm VLBW Babies in Relation to Gestational Age. The gestational age of studied neonate was from 28 weeks to $<37$ weeks

Distribution of babies according to number of pregnancy (parity) among the enrolled neonates about half $95(47.5 \%)$ babies were born to primipara mothers, rest to multipara mothers. Out of them $51(25.5 \%)$ were second pregnancy, 28(14\%) were 3rd pregnancy, $21(10.5 \%)$ 4th pregnancy and $5(2.5 \%) 5$ th pregnancy.

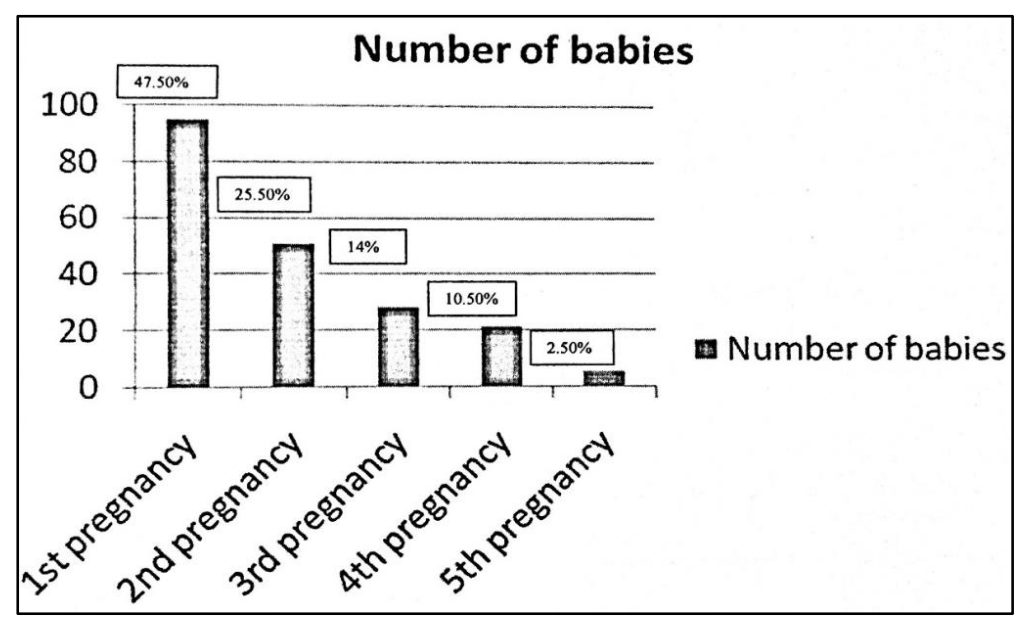

Fig-I: Distribution of babies according to number of pregnancies their maternal parity

Table-III: Distribution of mothers with different antenatal problems

\begin{tabular}{|l|l|l|}
\hline Antenatal problems & Number of babies & Percent (\%) \\
\hline Pre-eclamsia & 36 & $18 \%$ \\
\hline Eclamsia & 38 & $19 \%$ \\
\hline Antepartem haemorrage & 16 & $8 \%$ \\
\hline Premature rupture of membrane & 38 & $19 \%$ \\
\hline Gestational Diabetes mellitus & 5 & $2.5 \%$ \\
\hline Placenta previa & 2 & $1 \%$ \\
\hline Typhoid fever & 7 & $3.5 \%$ \\
\hline Leaking membrane & 16 & $8 \%$ \\
\hline Oligohydramnios & 3 & $1.5 \%$ \\
\hline Polyhydramnios & 2 & $1 \%$ \\
\hline Viral hepatitis & 18 & $9 \%$ \\
\hline History of trauma & 3 & $1.5 \%$ \\
\hline No antenatal problem & 16 & $8 \%$ \\
\hline
\end{tabular}

Among the 133 mothers most common problems were eclampsia 38(19\%), Pre eclampsia 36 $(18 \%)$, Premature rupture of membrane $38(19 \%)$,
Leaking membrane 16(8\%), Antepartem hemorrhage $16(8 \%)$, Viral hepatitis18 (9\%). 
Md. Alamgir Hossain et al; Sch J App Med Sci, Jan, 2022; 10(1): 87-91

Table- IV: Clinical outcome in relation to mode of delivery

\begin{tabular}{|l|l|l|l|l|l|}
\hline $\begin{array}{l}\text { Type of } \\
\text { delivery }\end{array}$ & $\begin{array}{l}\text { Died } \\
\mathbf{n}(\boldsymbol{\%})\end{array}$ & $\begin{array}{l}\text { Survival } \\
\mathbf{n}(\boldsymbol{\%})\end{array}$ & Total & $\mathbf{x}^{\mathbf{2}}$ & P value \\
\cline { 1 - 3 } & $47(36.4)$ & $82(63.6)$ & $129(64.5)$ & \multirow{2}{*}{38.34} & \multirow{2}{*}{0.001} \\
\hline C/S & $18(25.4)$ & $53(74.6)$ & $71(35.5)$ & & \\
\hline Total & 65 & 135 & 200 & & \\
\hline
\end{tabular}

Mortality rate was higher among those neonates who were delivered by normal vaginal route. Total number of babies delivered by vaginal route were
$129(64.5 \%)$ and of them died $47(36.43 \%)$, and by Caesarean section were $71(35.5 \%)$ and out of them died $18(25.4 \%)$

Table-V: Outcome in relation to morbidity during neonatal period

\begin{tabular}{|l|l|l|l|l|l|l|}
\hline Type of complaints & Total & Death & Percent & Survival & Percent & P Value \\
\hline 1.Birth asphyxia & 60 & 10 & 16.7 & 50 & $83.4 \%$ & $0.001^{\mathrm{S}}$ \\
\hline 2.Poor feeding & 20 & 03 & 15 & 17 & $85 \%$ & $0.001^{\mathrm{S}}$ \\
\hline 3.Septicaemia & 41 & 10 & 24.4 & 31 & $75.6 \%$ & $0.001^{\mathrm{S}}$ \\
\hline 4.Neonatal jaundice & 57 & 05 & 8.8 & 52 & $91.2 \%$ & $0.001^{\mathrm{S}}$ \\
\hline 5.Respiratory distress syndrome & 10 & 05 & 50 & 5 & $50 \%$ & $1.00^{\mathrm{NS}}$ \\
\hline 6.Congenital pneumonia & 10 & 03 & 30 & 7 & $70 \%$ & $0.081^{\mathrm{NS}}$ \\
\hline 7.Umblical sepsis & 15 & 00 & 00 & 15 & $100 \%$ & $0.001^{\mathrm{S}}$ \\
\hline 8.Apnoea & 33 & 06 & 18.2 & 27 & $81.8 \%$ & $0.001^{\mathrm{S}}$ \\
\hline 9.Cong.heartdisease & 05 & 02 & 40 & 3 & $60 \%$ & $1.00^{\mathrm{NS}}$ \\
\hline 10.Hypoglycaemia & 14 & 00 & 00 & 14 & $100 \%$ & $0.001^{\mathrm{S}}$ \\
\hline 11.Hypocalcaemia & 05 & 00 & 00 & 5 & $100 \%$ & $0.007^{\mathrm{S}}$ \\
\hline 12.Necrotizing enterocolitis & 10 & 04 & 40 & 6 & $60 \%$ & $0.654^{\mathrm{S}}$ \\
\hline 13.Neonatal seizure & 28 & 06 & 21.4 & 22 & $78.6 \%$ & $0.001^{\mathrm{S}}$ \\
\hline 14.Severe anemia & 07 & 02 & 28.6 & 5 & $71.4 \%$ & $0.286^{\mathrm{NS}}$ \\
\hline 15.Oral thrush & 24 & 00 & 00 & 24 & $100 \%$ & $0.001^{\mathrm{S}}$ \\
\hline 16.Intraventricular hemorrhage & 06 & 05 & 83.3 & 1 & $16.7 \%$ & $0.080^{\mathrm{S}}$ \\
\hline 17.Disseminated intravascular hemorrhage & 02 & 02 & 100 & 00 & $00 \%$ & $0.333^{\mathrm{NS}}$ \\
\hline 18.Hypothermia & 07 & 02 & 28.6 & 5 & 71.4 & $0.286^{\mathrm{NS}}$ \\
\hline Total & & 65 & & & & \\
\hline
\end{tabular}

Highest death rate was in disseminated intravascular hemorrhage $100 \%$ ) and followed by intra ventricular hemorrhage $(83.33 \%) \&$ respiratory distress syndrome $(50 \%)$. Significant association were found between morbidity and mortality like congenital pneumonia, Respiratory distress syndrome, Severe anemia, disseminated intravascular hemorrhage, Hypothermia but no significant association $(\mathrm{P}<0.05)$ was found in between mortality and asphyxia, poor feeding, sepsis, hypoglycemia, hypocalcemia, apnea.

\section{DISCUSSION}

In this study mortality rate of female babies was $28 \%$ and in male babies was $37 \%$. Mortality rate of male babies was $9 \%$ higher than female babies. Slight preponderance of male mortality probably male baby more fragile than female [12]. It is consistent with study of Ali Manajjir [11] who found the mortality rate of male babies $(55.17 \%)$ was higher than female babies $(42.86 \%)$.

Out of total 200 studied $100(50 \%)$ were male and $100(50 \%)$ were female. Out of them $135(67.5 \%)$ recovered \& $65(32.5 \%)$ died. Out of total 100 male babies $63(63 \%)$ recover and $37(37 \%)$ died. Out of total 100 female babies $72(72 \%)$ recover and $28(28 \%)$ died.

In this study mortality rate of female babies was $28 \%$ and in male babies was $37 \%$. Mortality rate of male babies was $9 \%$ higher than female babies. Slight preponderance of male mortality probably male baby more fragile than female.

It is consistent with study of Ali Manajjir [11], who found the mortality rate of male babies $(55.17 \%)$ was higher than female babies $(42.86 \%)$.

According to gestational age mortality rate 28 weeks-100 \%, 29-30 weeks $100 \%, 31-32$ weeks 100 $\%, 33-34$ weeks $16.33 \%, 35-36$ weeks $00 \%$, $<37$ weeks $00 \%$. Among them.

28 wks-00\%, 29-30wks-00\%, 31-32wks-00\%, $33-34$ wks-61\%, 35- 36wks-100\%, 37wks-100\%. It is consistent with study of Ali Manajjir, 11. In his study the mortality rate was $<28$ wks $-100 \%, 29-32$ wks$70.00 \% \quad 33-36$ wks $-32.75 \% \quad \&<37$ wks $00 \%$ gestational age group respective. 
Md. Alamgir Hossain et al; Sch J App Med Sci, Jan, 2022; 10(1): 87-91

According to birth weight mortality rate -700 750gm-100 \%) 800-985 gm-100 \%, 995 gm-24.57\%, 1 kg-26.67\%, $1.2 \mathrm{~kg}-55.56 \%, 1.25 \mathrm{~kg}-18.87 \%, 1.3 \mathrm{~kg}-$ $21.74 \%, 1.35 \mathrm{~kg}-18.18 \%, 1$

$.4 \mathrm{~kg}-7.35 \%, 1.45 \mathrm{~kg}-13.51 \%, 1.48 \mathrm{~kg}-18.42$ $\%$. It is consistent with study of Ali Manajjir [13], The survival rate of $1000-1249 \mathrm{~g} \& 1250-1499 \mathrm{~g}$ weight group were $36 \% \& 80 \%$ respectively.

Place of delivery has a great impact on the survival. of a newborn [38]. In my series 135 (67.50\%) were born in Hospital, $34(17 \%)$ babies in clinic \& $29(14.50 \%)$ infants were home delivery and $02(1 \%)$ in the Ambulance. Among them 102 (75.56\%) 17 (50\%), $14(48.28 \%), 02(100 \%)$ recovered respectively and $33(24.44 \%), 17(50 \%), 15(51.72 \%), \quad 00(00 \%)$ died respectively.

This finding is very much conformity with the finding of Manajjir Ali [11], he found 45\% inborn survived $44 \%$ survived among the other institutional delivery and non-survived who were delivered at home. Antenatal checkup has a great influence in the outcome of VLBW babies. In my series-45 $(22.5 \%)$ babies had history of maternal regular antenatal checkup 7 (28.5 $\%$ ) babies had irregular antenatal checkup, 98(49\%) babies had no antenatal checkup at all. Among them $35(77.78 \%), 65(66.33 \%)$ survived respectively and $10(22.22 \%), 22(36.60 \%), 33(33.67 \%)$ died respectively.

In my study prenatal asphyxia encountered the commonest presentation at admission. Total 60 (30\%) infants presented with prenatal asphyxia. Overall mortality rate of prenatal asphyxia was $10(16.67 \%)$.

Shahnawaz found $32 \%$ incidence of prenatal asphyxia in his series of VLBW babies. Ali Mamqjir [11], found $34 \%$ prenatal asphyxia in his series of which $82 \%$ died.

This study is in near conformity whit the study of Banu at1 [14] found $13.43 \%$ of prenatal asphyxia among 87 babies and per entage of mortality was $44.40 \%$ among these cases.

\section{Conclusions}

This study was an enthusiastic approach towards finding out morbidity and mortality pattern the outcome in preterm very low birth weight babies in neonatal period.

\section{REFERENCE}

1. Lee, K. G., \& Cloherty, J. P. (2004). Identifying the high risk newborn and evaluating gestational age, prematurity, post-maturity, large-for-gestationalage and small-for-gestational age infants. Manual of neonatal care, 51, 53.

2. James, H, Rose., Richard, L. (1985). Practical approach to apnea in newborn-World pediatrics and child care, 1; 13-23.

3. Ganong, W.F. (2000). editros. Review of Medical physiology.20th edition. New Jersy; prentice-Hall International Inc. A Lange Medical book, 594-600.

4. Banu, K., Rahman, S. (1982). Disease rattem in the neonatal period, Bangladesh pediatrics, 6 (30:40)

5. Islam, M.N. (2000). Situation of Neonatal Health in Bangladesh. Orion Medical Journal May; 6: 4-6.

6. William, W, Hay, Jr. (2002). The pretenn infant. In current pediatric diagnosis and treatment. 17th ed. New York: McGraw-Hill Book Company, 29-32.

7. Pay, S., Bhattacharya, I., Gupta, M.D. (1994). Low Birth weight infants-study of mortality Indian paediatric, $2 ; 38$.

8. Banik, S. (1984). Disease pattern in neonatal period, Bangladesh paediatrics, 3; 24. 9.

9. Gupte, S. (20001). The Short Textbook of Pediatrics.9th ed. New Delhi: Jaypee Brothers; 530-47.

10. Peacock, W.G., Hirala, J. (1981). Outcome in low birth weight infants. AMJ Obstet Gynae, col, 14065.

11. Ali Manajiir. (1987). Outcome of very low birth weight infants in a referral hospital Dissertation for FCPS.

12. Commentary on current -World Health Organization definitions used in Prenatal Statistics. (1986). Arch. Dis. Child, 61; 708-10.

13. UNICEF. (2003). The state, of world's Children 2003. p 83-9.

14. Jlling, worth, R.S. (1982). Cyanotic attack in newborn 32.Banu Khaleda, Rahman Shafique, Disease pattern in neonatal period. Bangladesh pediatrics, 6(3); 4 infants. Arch. Dis. Child 1957; 32:328-32. 